\title{
HIV- TRANSMISSÃO MATERNO-FETAL (REVISÃO)
}

\author{
Ledice Inácia de Araújo Pereira
}

\section{RESUMO}

O número de mulheres infectadas com o Vírus da Imunodeficiência Humana vem aumentando nos últimos anos em consequência do uso de drogas injetáveis, múltiplos parceiros sexuais ou parceiro único HIV positivo ou em situaçð̃es de risco. A transmissão materno-fetal varia de 14 a $30 \%$ e está relacionada com as características do vírus infectante, infeç̧ão primária durante a gravidez, doença materna avançada, estado imunológico da gestante, gestação pré ou pós-termo e o tipo de parto. Revisamos os tipos de transmissão mãe/filho, métodos diagnósticos e recomendaçð̃es para prevenção, incluindo o uso de Zidovudine.

UNITERMOS: HIV; AIDS; Transmissão materno-fetal.

A Síndrome de Imunodeficiência Adquirida é uma pandemia em progressão, especialmente em países subdesenvolvidos. Em parte da Europa, América do Norte e entre nós a doença predomina em homens homossexuais e bissexuais mas é crescente o número de casos em usuários de drogas injetáveis. Conseqüentemente, a transmissão heterossexual vem aumentando nos últimos anos atingindo um número cada vez maior de mulheres. No final da década de 80 , no Brasil, a relação era de 9 homens infectados para 1 mulher e em 1994 de $3 / 1$. Estima-se que no ano 2000 teremos no mundo 15 milhões de mulheres e 3 milhões de crianças com a infecção. O índice de transmissão vertical varia de 14 a $30 \%$ enquanto que nos países subdesenvolvidos, principalmente na África, chega a 45\%. A infecção pelo HIV, nas mulheres, está relacionada com o uso de drogas injetáveis, múltiplos parceiros sexuais ou parceiro único HIV positivo ou em situações de risco

\footnotetext{
- Professora Adjunta do Departamento de Medicina Tropical IPTSP / UFG.
}

Recebido em 18/06/96. 
múltiplos parceiros sexuais, usuários de drogas injetáveis, hemofílicos e com antecedentes de transfusão de sangue e derivados.

Os fatores de risco, geralmente associados com a transmissão vertical do HIV são: características do vírus infectante, infecção primária durante a gravidez doença materna avançada, estado imunológico da gestante (redução de CD4, elevação de CD8 e presença de antigenemia P24), gestação pré-termo (< 37 semanas), gestação pós-termo ( $>42$ semanas) e o tipo do parto (normal ou cesáreo).

A transmissão mãe/filho pode ser intra-uterina, intra-parto e pós-parto sendo que 50 a $70 \%$ ocorre no final da gestação e durante o trabalho de parto. Características que evidenciam o tipo de transmissão:

1- intra-uterina: identificação do HIV na placenta, no tecido fetal e no recém-nascido, além do início precoce dos sintomas na criança.

2- intra-parto: HIV isolado em secreções vaginais e cervicais, exposição ao sangue materno, identificação viral mais tardia na criança e também início tardio dos sintomas.

3- pós-parto: HIV isolado do leite materno, estudos prospectivos comparando crianças amamentadas com outras não amamentadas e ausência de transmissão por contato social nos domicílios.

$O$ diagnóstico de HIV/AIDS na mãe é realizado através da pesquisa de anticorpos anti-HIV pela técnica de ELISA seguida de um teste confirmatório como a Reação de Imunofluorescência Indireta ou Western Blot. Na criança pode-se fazer o acompanhamento da persistência de anticorpos anti-HIV até 15 ou 18 meses para eliminar a possibilidade de transferência materna. Mas, a conduta mais adequada seria a pesquisa de Antigenemia P24, o Isolamento do Vírus e especialmente a Reação em Cadeia de Polimerase (PCR) que se apresenta positiva em cerca de $75 \%$ das crianças ao nascimento e em $95 \%$ entre 3 e 6 meses de vida.

A prevenção da transmissão vertical da infecção pelo HIV deve ser prioridade nos serviços de saúde. As recomendações fundamentais são:

1- Campanhas de esclarecimento quanto aos riscos de transmissão;

2- Tratamento das usuárias de drogas;

3- Orientação das mulheres em fase de procriação quanto aos métodos anticoncepcionais adequados à sua situação clínica;

4- Teste anti-HIV para mulheres com fatores de risco para a infecção e/ou habitantes de áreas de alta prevalência;

5- Uso de Zidovudine (AZT) em grávidas infectadas a partir da $14^{\mathrm{a}}$ semana de gestação na dose de $100 \mathrm{mg}$ cinco vezes por dia e durante o trabalho de parto infusão venosa contínua de $2 \mathrm{mg} / \mathrm{kg}$ na primeira hora seguido de $1 \mathrm{mg} / \mathrm{kg} /$ hora. Manter a medicação no recém-nascido por 6 semanas ( $2 \mathrm{mg} / \mathrm{kg}$ de $6 / 6$ horas) iniciando 8 a 12 horas após o nascimento. $\mathrm{O}$ Zidovudine diminui a viremia materna, é seguro quando utilizado por
PEREIRA, L.I.A. HIV- Transmissão materno-fetal (revisão). Rev. Pat. Trop.25 ( 1 ): 1-4, jan/jun. 1996

períodos curtos e atinge a placenta. Em trabalho recente mostrou redução de $67,5 \%$ do índice de transmissão,

6- Evitar o aleitamento materno;

7- O parto cesariano tem mostrado risco um pouco menor de transmissão da infecção, mas por outro lado o parto normal é mais seguro para a equipe. Deste modo a indicação de cesárea deve ser a mesma utilizada para gestantes não infectadas.

As recomendações para atendimento ambulatorial e hospitalar de pacientes com HIV/AIDS se resumem às Precauções com Sangue e Secreções: lavar as mãos antes e após o exame do doente; uso de luvas, óculos protetores, máscaras e avental quando houver risco de contaminação com sangue e/ou secreções; e manipulação cuidadosa de agulhas, escalpes e instrumentos cortantes.

\section{SUMMARY}

\section{HIV - Maternal - fetal transmission (review)}

The number of women infected with the human immunodeficiency virus (HIV) has been growing in the last years due to the use of injectable drugs, multiple sexual partners or HIV positive single partner or in risk involving situations. The maternal - fetal transmission occurs in 14 to $30 \%$ of cases and is related to the infecting virus characteristics, primary infection during pregnancy, advanced maternal disease, imunological status of the pregnant woman, term or post-term pregnancy and the type of labor. We have reviewed the types of mother/son transmission, diagnostic methods and recommendations to prevention, including the use of zidovudine.

KEYWORDS: HIV; AIDS; Maternal - fetal transmission.

\section{REFERÊNCIAS BIBLIOGRÁFICAS}

01.ADJORLOLO-JOHNSON, G.; DE COCK K.M.; EKPINI, E. et al. Prospective Comparaison of Mother-to-Child Transmission of HIV-1 and HIV-2 in Abidjan, Ivory Coast. JAMA 272: 462Mother-to-C
466, 1994.

02.AIDS CLINICAL CARE. Management of HIV Infection During Pregnancy: New Options, New Questions. June 7: 46-49, 1995.

03.BLANCHE, S.; MAYAUX, M.J.; ROUZIOUX, C. et al. Relation of the Course of HIV Infection in Children to the Severity of the Disease in their Mothers at Delivery. N Engl J Med. 330: 308-312, 1994.

04.CONNOR, E.M.; SPERLING, R.S.; GELBER, R. et al. Reduction of Maternal-Infant Transmission of Human Immunodeficiency Virus Type 1 with Zidovudine Treatment. N Engl J Med. 331: I173$80,1994$. 
05.DOUGLAS, S.D. Immunological and Virological Clues for Mother-to-Child Transmission of HIV-1 and HIV-2. JAMA 272: 487-488, 1994.

06.KATZ, S.L. \& WILFERT, C.M. Human Immunodeficiency Virus Infection of Newborns. N Engl J Med. $320: 1687-1688,1989$.

07.KLIKS, S.C.; WARA, D.W.; LANDERS, D.V. \& LEVY, J.A. Features of HIV-1 that Could Infuence Maternal-Child Transmission. JAMA $272: 467-474,1994$.

08.MINISTÉRIO DA SAÚDE. DIVISÃO NACIONAL DE CONTROLE DE DOENÇAS SEXUALMENTE TRANSMISSÍVEIS-SIDA/AIDS. Normas Técnicas para Prevenção da Transmissão do HIV nos Serviços de Saúde. Brasília, 1989.

09.ROGERS, M.F.; OU, C.Y.; RAYFIELD, M. Use of the Polimerase Chain Reaction for Early Detection of the Proviral Sequences of Human Immunodeficiency Virus in Infants Born to Seropositive Mothers. N Engl J Med. 320 :1649-1654, 1989.

10.ROGERS, M.F. \& JAFFE, H.W. Reducing the Risk of Maternal-Infant Transmission of HIV: A Door is Opened. N Engl J Med. 331:1222-1223, 1994.

11.SPERLING, R.S.; STRATTON, P.; O"SULLIVAN, M.J. A Survey of Zidovudine Use in Pregnant Women with Human Immunodeficiency Virus Infection. N Engl J Med. 326: 857-861, 1992.

12.SPERLING, R.S.; STRATTON P AND THE MEMBERS OF THE OBSTETRIC-GYNECOLOGIC WORKING GROUP OF THE AIDS CLINICAL TRIALS GROUP OF THE NATIONAL INSTITUTE OF ALLERGY AND INFECTIOUS DISEASES. Treatment Options for Human Immunodeficiency Virus-Infected Pregnant Women. Obstet Gynecol. 79: 443-448, 1992.

13.ST. LOUIS, M.E.; KAMENGA, M.; BROWN, C. et al. Risk for Pernatal HIV-1 Transmission According to Maternal Immunologic, Virologic, and Placental Factors. JAMA 269: 2853-2859, 1993.

14.THE EUROPEAN COLLABORATIVE STUDY. Caesarean Section and the Risk of Vertical Transmission of HIV-1 Infection. Lancet 343: 1464-1467, 1994.

15.TOVO, P.A. Caesarean Section and Perinatal HIV Transmission: What Next? Lancet 342: 630, 1993. 